Original Research Paper

\title{
Corporate Governance on the Corporate Characteristics- Managerial Accounting link
}

\author{
Quang Linh Huynh \\ School of Economics and Law, Tra Vinh University, \\ No. 126 Nguyen Thien Thanh Street, Ward 5, Tra Vinh City, Vietnam
}

Article history

Received: 30-12-2016

Revised: $18-05-2017$

Accepted: 24-05-2017

Email: huynhquanglinh@tvu.edu.vn

\begin{abstract}
The objective of this article attempts to investigate the intervening impact of corporate governance on the causal link between corporate characteristics and the application of managerial accounting, which has not been discussed and empirically investigated in the prior literature. A successful survey of 395 publicly listed firms in Vietnam offers experimental evidence that corporate characteristics indirectly contribute to the application of managerial accounting via corporate governance. This research further investigates whether the causal association from corporate governance to the application of managerial accounting is moderated by corporate characteristics, which has been ignored by prior research. The findings reveal that corporate characteristics impose a moderating influence on the corporate governance- managerial accounting causal linkage. The current research contributes to the management literature by shedding light on the intricate associations among corporate governance, corporate characteristics and the application of managerial accounting in that the mediation of corporate governance and the moderation of corporate characteristics are clarified. The findings are also expected useful to executives in helping for better decisions on the application of managerial accounting tools in business, appropriate to their corporate governance structure and corporate characteristics in order to receive the best possible corporate performance.
\end{abstract}

Keywords: Corporate Governance, Managerial Accounting, Corporate Characteristics

\section{Introduction}

Principal-agent relationships associated with corporate governance, have been analyzed quite so much in the literature of management (Jensen and Meckling, 1976). In a broad sense, corporate governance is identified as the structure for running and controlling firms, which is related to the links among stakeholders, especially between managers (agents) and shareholders (principals). According to Huynh (2015), the conflicts of interests among stakeholders can be moderated by a good corporate governance structure. In the similar sense, that research also emphasizes the important role of corporate governance in declining agency costs anchored in the ownership- management link. The decrease of agency costs often build competitive advantages, so eventually leading to improved corporate performance and sustainable economic development (Cadbury, 1992). Similarly, in a study on firm value, Mangantar and Ali
(2015) recommend the close relations of corporate governance to operating performance and firm value; and indicate that, corporate performance depends upon corporate governance and also that a good corporate governance structure will create added value and so improve corporate performance.

In another respect, managerial accounting is normally mentioned as a significant control technique in offering executives with useful information for maintaining effective supervision over corporate resources and consequently making good business decisions. Additionally, Johnson and Kaplan (1987) provide evidence on the usefulness of managerial accounting tools in providing timely and proper information for the management of business expenses, the improvement of productivity and the facilitation of pricing decision. Numerous researchers (Otley, 1999; Fullerton and McWatters, 2001; Haldma and Laats, 2002; Hoque et al., 2001; Kaplan and Atkinson, 1998) have emphasized the 
importance of advanced managerial accounting tools, for instance activity based costing, balanced scorecard or total quality management, being supposed to supplement for traditional ones, such as variance analysis, cost volume profit analysis or traditional budgeting, in satisfying the needs of the contemporary administration. The novel managerial tools have imposed an influence on the entire process of managerial accounting, transferring its simple task of financial determination to a more intricate task of producing corporate performance by making the best uses of accessible corporate resources. Besides, implied in a study on balanced scorecard by Caldarola (2016), balanced scorecard as a part of the managerial accounting system is a causality of organizational performance; while, corporate governance is suggested to positively impact on the application of managerial accounting tools for business (Cromie et al., 1995; Salvato and Melin, 2008; Sam et al., 2012; Christine et al., 2011). From the work by Baron and Kenny (1986), it can suggest an intervention of corporate governance in the impact of corporate characteristics on the application of managerial accounting tools. Nevertheless, that intervenient influence has not been statistically investigated so far. In order for this intervenient influence of corporate governance to be examined, Sobel (1982) offers an analytic procedure for a third mediating variable. This research attempts to discuss the intervenient role and then investigates how and whether corporate governance statistically intervenes in the impact of corporate characteristics on the application of managerial accounting tools in business. It is expected to be the first to explore the intervenient role of corporate governance, offering business managers and scholars in the research field with a better insight into the importance plaid by corporate governance in the application of managerial accounting tools in business. The results are also believed helpful to executives in deciding appropriate managerial accounting tools to their corporate characteristics and corporate governance structure that will bring to the firm with better corporate performance. The research will go on in the following structure. Subsequent is "Conceptual framework" that will systematize the related review literature; then propose research hypotheses. Next, the research methodology will show the measurement of the research variables and the research data collection and analyses. Next, the empirical results and discussion will deal with the findings. Finally, the conclusions are to summarize the findings.

\section{Conceptual Framework}

Corporate characteristics, the application of managerial accounting and corporate governance are three main analytic variables which the links between and among are quite complicated. More detail for those links will be discussed hereafter. In respect of corporate governance, Cadbury (1992) considers it as a administrative instrument to deal with the agency problems due to the consequence of the principal-agent relationship. Additionally, mentioned by Mayer (1997), corporate governance is ways to ensure the interests of stakeholders including customers, suppliers, shareholders, management, financiers, the community and the government into line. They often link corporate governance to the function and composition of corporate managerial and supervisory boards. Grounded on the suggestions by prior studies (Edwards and Clough, 2005; Brown and Caylor, 2004; Bhagat and Bolton, 2008; Kyereboah-Coleman, 2007), in this research, corporate governance is referred to as compositions of directory and supervisory boards and as the duality of chief executive officers, the situation where the positions of chief executive officer and chairman are undertaken by an individual.

Another factor analyzed is the application level of managerial accounting tools for organization. Managerial accounting is a managing tool providing required nonfinancial and financial information that helps for business decisions. Likewise, managerial accounting is also proposed by Kaplan (1983) as a technique for controlling. Its main function is to give vital business information facilitating the process of planning and so improve corporate operating outcome. Moreover, Lucas (1997; Kaplan, 1983) advocate traditional managerial accounting practices, namely variance analysis, cost volume profit analysis and traditional budgeting are only financially oriented and focus on internal concerns to the organization. They are no longer considered as a helpful managerial instrument due to the failure to produce satisfactory information for controlling and planning in the current unstable environment. Besides those traditional managerial accounting tools, Lucas (1997) persists that firms ought to try to link their managerial system to more sophisticated managerial techniques, for example balanced scorecard, total quality management and activity based costing, satisfying the requirements of relevant stakeholders. Grounded on these above mentioned standpoints, it can refer to the application of managerial accounting as the extent of adopting managerial accounting tools within a firm, including both the advanced and traditional managerial accounting tools in business. Furthermore, corporate governance is suggested as a determinant leading to applying managerial accounting tools within a firm. It is asserted by Salvato and Melin (2008), if outside outstanding managers with good qualifications, experience and expertise are empowered to run organizations, the formalization within a firm is more likely increased. In the same idea, Cromie et al. (1995) confirm that, the outside directors are obliged to regularly report to their shareholders on business tasks; they thus require formal managerial instruments to run organizational activities effectively. 
In addition, the research on managerial accounting and corporate governance of Christine et al. (2011) highlights the necessities that should set up an independent division dealing with managerial accounting, because managerial accounting is useful to the formal situation. That research also reflects that, professionalization of outside directors is closely relevant to the application of more complicated managerial accounting tools. Moreover, Agrawal and Chadha (2005) finds out the likelihood of restatement is less in companies where supervisory and directory boards consist of outside financial directors, but more in companies whose chief executive officers are ones of the big shareholders. That is because outside directors need to apply formal managerial tools for more faithful business reports. As a result, corporate governance structure can be regarded as a connected factor to the application of managerial accounting tools in business. Additionally, Htay and Salman (2013) in a study of balanced score card and corporate governance, propose an association between balanced score card- a managerial accounting practice and corporate governance. In the same year, Waweru and Riro (2013) also recommend a relationship between corporate governance and earnings management concerning some accounting techniques. Similarly, Wang and Huynh (2014; Huynh, 2015) advocate a significant association between the application of managerial accounting tools in business and corporate governance. They offer statistical evidence that the application of managerial accounting tools in business is dependent on corporate governance. Those underpinnings propose that the application of managerial accounting tools in business can be influenced by corporate governance $(\mathrm{H} 1)$.

In this research, the contingency theory of managerial accounting is applied to analyze the causal linkages from explanatory factors to the application of managerial accounting tools in business. This theory is to explain the effect of the contextual variables in the application of managerial accounting techniques in business. Drawing on the contingency theory, Galbraith (1973) confirms there is no best way to arrange a firm and ways of arranging are not similarly effective. Moreover, some previous research recommends the viewpoint that no control tool is best for all the types of organizations and the context faced by the organization will specify what managerial tools are most appropriate for that organization (Fisher, 1995; Waterhouse and Tiessen, 1978). Those perspectives are consistent to that of Horngren (1982) reflecting the application of managerial tools in business is determined by the firm's business characteristics. Concerning corporate characteristics, some earlier studies (Saad et al., 2009; Nimtrakoon and Tayles, 2010) refer to it as firm industry type and corporate size; however, Miller (1993) defines industry and corporate-specific variables as a kind of managerial uncertainties affecting managers' business decision. The third research variable is corporate characteristics referred to as corporate business size, informationintensity and industry sector (suggested by Breen et al., 2003). Two years later, Sankaran and Kouzmin (2005) identify corporate characteristics as a factor including business size, business process, corporate structure and departmental integration. Based on those arguments, this research integrates corporate type (industry characteristics) to corporate characteristics. Finally, the variable "corporate characteristics" is constructed with three dimensions; namely corporate size, type and interdependence. Further, Wierenga and Ophuis (1997) allege corporate characteristics shape organizations' decisions to operate managerial tools in business. For the information technology context, corporate characteristics are suggested by $\mathrm{Chen}$ and $\mathrm{Fu}$ (2001) to identify the trends of information technology application in business. According to Mellahi and Eyuboglu (2001), corporate characteristics are very essential to the adoption of the quality management tool in business. A year afterwards, a study by Haldma and Laats (2002) find out corporate characteristics as a determinant of the application of the control system in business. While Warwood and Roberts (2004) underline a significant impact of corporate characteristics on the application of the quality managerial tool for business; Al-Omiri and Drury (2007) conclude the application of the managerial accounting tools in business is very changing according to corporate characteristics. After that, Abdel-Kader and Luther (2008) confirm the relationship between the application of managerial systems and corporate characteristics; while Masrek (2009) finds out corporate characteristics determines the use of management information systems within an organization. Additionally, the utilization of accounting programs investigated by Nitaya et al. (2010) is also conditional upon corporate characteristics. Furthermore, Erserim (2012) in a study on corporate characteristics and management accounting tools contends that corporate characteristics as an internal variable very imperative to the application of managerial accounting tools for an organization. Likewise, corporate characteristics are referred to as a contingent factor determining the applying level of management accounting in business (Al-Mawali, 2015). With respect to the link between corporate characteristics and earnings management relevant to accounting, Bassiouny et al. (2016; Waweru and Riro, 2013) emphasize the role of corporate characteristics in earnings management. Overall, for the accounting context, it can hypothesize that the application of managerial accounting tools in business is decided by corporate characteristics $(\mathrm{H} 2)$.

On the one hand, corporate characteristics put effects on the application of managerial accounting tools in business; on the other hand, this factor is also a driving force of corporate governance. Soltani (2005) with a project of "Factors affecting corporate governance and audit committees in selected countries" argues for the 
effect of organizational variables to the governance structure of the firm. Moreover, Demsetz and Lehn (1985) point out corporate characteristics impose an significant effect on corporate governance structure. Correspondingly, corporate-specific variables are revealed by Soltani (2005) to have a close relationship with firms' current structure of corporate governance. In addition, implied from a study on corporate governance carried out by Altunoglu (2012), corporate governance is conditional on organizational variables such as corporate characteristics. Equally, Chadha (2015) prove a correlation exists between corporate governance and corporate characteristics. Those above mentioned discussions could conjecture that corporate characteristics determines corporate governance (H3).

Grounded on the above arguments, applying managerial accounting systems in business is much dependent on corporate governance; while both the factors are suggested as the consequence of corporate characteristics. The relations among the application of managerial accounting in business, corporate characteristics and corporate governance are quite complicated. Corporate governance is both a causal and resulting factor; therefore it is regarded as a third factor. Based on Baron and Kenny (1986), that third factor may intervene in the relationships among the other factors. It is essential to discover the intervenient impacts where the mediation occurs in the research model; so Baron and Kenny (1986) establish an intervenient frame, in which a factor may be considered a mediator, which can carry the partial effect of a given independent factor to a given dependent factor. When the three conditions occur together, it can conclude there exists interference in the research model. Firstly, an independent factor is statistically related to an intermediate factor. Secondly, that independent factor statistically affects on a dependent factor in the absence of that intermediate factor. Thirdly, the intermediate factor puts a statistical unique impact to that dependent factor. Additionally, adding the intermediate factor to the analytic model would lessen the effect of the independent factor on the dependent factor. Furthermore, Spencer (2011) and Mia (1988) find out if there is a relationship between two factors at least partially via a third factor, the third factor may intervene in the linkage between those two factors. The above arguments arrive at the supposition that corporate governance could interfere with the association between corporate characteristics and the application of managerial accounting tools for business (H4).

\section{Research Methodology}

In the world, the economic growth of the Asia is currently fastest, especially in emerging economies of the Southeast Asia, including Vietnam. This country is selected as a case study for analysis in the current study, since it is a fast developing market in the Southeast Asia. The sample for this study is a population of the public companies in the Stock Exchanges in Vietnam, entirely including 1130 listed companies. A pilot test was carried out with 10 experts in corporate governance and managerial accounting to check the validity of measurements in the research model (Donna et al., 2011). The 450 listed companies were chosen to deliver with the research questionnaires. The responses without necessarily adequate information were removed. Finally, only 395 responses contain sufficiently required information. This number of observations meets the requirement proposed by Hair et al. (2010). The factors used for analyses are measured as follows. Corporate Governance (QTDN) is referred to as the majority of independent directors (QTDN1), independent supervisors (QTDN2) and the duality of chief executive officer and chairman (QTDN3) (Brown and Caylor, 2004; Kyereboah-Coleman, 2007; Edwards and Clough, 2005; Bhagat and Bolton, 2008). Application of Managerial Accounting Tools (KTQT) is assessed with a five-point scale, ranging from 1.never considering, 2.decided not to introduce, 3.favored to introduce, 4.intended to introduce, to 5.under implementation of managerial accounting tools in business (Cinquini et al., 2008).

The observed variables are traditional budgeting (KTQT1), cost volume profit analysis (KTQT2), variance analysis (KTQT3), activity based costing (KTQT4), total quality management (KTQT5) and balanced scorecard (KTQT6) (Hyvonen, 2005; Al-Omiri and Drury 2007; Lucas, 1997). Corporate Characteristics (DTQDN) is measured with corporate size, corporate type and corporate interdependence. Corporate size (DTDN1) is evaluated on with three level (adapted from Nguyen, 2009). Corporate type (DTDN2) is estimated with a three-point scale that includes three levels with 1.manufacturing sector, 2.manufacturingservice sector and 3.service sector (Brouthers et al., 2002; Taha et al., 2011). Corporate interdependence (DTDN3) is measured with a three-point scale (Ibadin and Imoisili, 2010; Chenhall and Morris, 1986). After the data was collected and cleaned, the reliability analysis is employed. Then, regression analyses are conducted to investigate the causal associations in the analytic model. After that, the procedure for the mediating effect was used for the intermediary influence of corporate governance.

\section{Empirical Results}

The cleaned data was entered to the reliability analysis that refers to the fact that a scale should consistently reflect the construct it is measuring. The results are shown in Table 1. The item-total correlations among DTDN1, DTDN2 and DTDN3 are larger than 
those among KTQT1, KTQT2, KTQT3, KTQT4, KTQT5 and KTQT6. The item-total correlations among QTDN1, QTDN2 and QTDN3 are the smallest. All the item-total correlations are bigger than the smallest accepted limit (Hair et al., 2010). In addition, all the Cronbach's alphas surpass 0.7 , the minimum acceptable limit (Hair et al., 2010). As a result, all these items are reasonably kept for next steps.

The reliable data was entered for next analyses. The causal links in this study are examined with regression analyses. The results of those regression analyses are exhibited in Table 2, indicating the application of managerial accounting tools within a firm are significantly influenced by both corporate governance and corporate characteristics at the $1 \%$ significance level. Corporate governance affects the applying level of managerial accounting tools in business at the coefficient of 1.000; while corporate characteristics influences the applying level of managerial accounting tools in business at the coefficient of 0.186 , meaning that the influential level of corporate governance to the adoption of managerial accounting tools within a firm is stronger than that of corporate characteristics. A good corporate governance structure will enhance applying managerial accounting tools in business. Similarly, corporate characteristics are also influential in applying managerial accounting tools in business. In the research model, on the one hand corporate governance is influential in the application of managerial accounting tools in business; on the order hand it is dependent on corporate characteristics. The causal relationship between corporate characteristics and corporate governance is statistically supported at the 5\% significance level and at the affecting coefficient of 0.058 ; which imply that in addition to affecting the application of managerial accounting tools in business, corporate characteristics are also influential in structuring corporate governance of the firm. So far, hypotheses $\mathrm{H} 1, \mathrm{H} 2$ and $\mathrm{H} 3$ in the research model are statistically examined. The empirical results well support these hypotheses at the 1 and 5\% statistical significance levels.
Corporate characteristics alone explain $0.46 \%$ (untabulated) of variation in the application of managerial accounting tools in business. Nevertheless, the explanation goes up to $2.04 \%$ (untabulated), when corporate governance is taken into account along with corporate characteristics to explain the application of managerial accounting tools. The addition of corporate governance into the research model will decrease the influential level of corporate characteristics on the application of managerial accounting tools in business from 0.244 (untabulated) down to 0.186 as in Table 2. Those findings suggest that there is mediation of corporate governance in the relationship between corporate characteristics and the application of managerial accounting tools in business. That intervenient effect of corporate governance are explored with the mediating analysis, employing a t-test to check the indirect influence. The t-statistics is computed with the following formula $\left(t_{\text {indirect }}=\frac{b_{\text {indirect }}}{s_{b_{\text {indreat }}}}\right)$. The findings of that mediating procedure are shown in Table 3, providing statistical evidence on the mediatory influence of corporate governance on the causal linkage between corporate characteristics and the application of managerial accounting tools in business. The influence of corporate characteristics on the application of managerial accounting tools within a firm is mediated by corporate governance with t-statistics of 2.425 at the $5 \%$ significance level. That evidence offers a statistical support on the hypothesis H4 stating that corporate governance puts a mediating effect in the causal link between corporate characteristics and the application of managerial accounting tools in business. This means that when entered in the research model together with corporate characteristics and the application of managerial accounting tools, corporate governance will reduce the direct influence of corporate characteristics on the application of managerial accounting tools within an organization.

Table 1 . Reliability analyses

\begin{tabular}{llll}
\hline Dimension & Total correlation & Cronbach's alpha & Number \\
\hline DTDN1 & 0.766 & 0.885 & 3 \\
DTDN2 & 0.801 & & 3 \\
DTDN3 & 0.766 & 0.736 & \\
QTDN1 & 0.521 & & \\
QTDN2 & 0.534 & 0.889 & 6 \\
QTDN3 & 0.670 & & \\
KTQT1 & 0.683 & & \\
KTQT2 & 0.690 & & \\
KTQT3 & 0.675 & & \\
KTQT4 & 0.766 & & \\
KTQT5 & 0.830 & 0.611 & \\
KTQT6 & &
\end{tabular}


Table 2. Result of regression analysis

\begin{tabular}{lllll}
\hline Explained variable & Explanatory variable & Coefficient & Standard error & $t$-statistics \\
\hline KTQT & Constant & 2.717 & 0.126 & $21.578^{* * *}$ \\
& QTDN & 1.000 & 0.113 & $8.818^{* * *}$ \\
& DTDN & 0.186 & 0.052 & $3.579^{* * *}$ \\
QTDN & Constant & 0.722 & 0.043 & $16.981^{* * *}$ \\
& DTDN & 0.058 & 0.023 & $2.546^{* *}$ \\
\hline
\end{tabular}

$* * *, * *$ Significance level at the 1 and $5 \%$

Table 3. Mediating analysis

\begin{tabular}{lll}
\hline Mediating Variable & Effect & $t_{\text {indirect }}$ \\
\hline QTDN & DTDN on KTQT & $2.425^{* *}$ \\
\hline
\end{tabular}

**Significance level at 5\%

In addition, on the one hand corporate characteristics are given to affect the structure of corporate governance; it in contrast is also suggested to determine the application of managerial accounting tools within a firm, which is dependent on the structure of corporate governance. Those arguments lead to the suggestions that the correlation between corporate governance and the application of management accounting tools can be moderated by corporate characteristics. However, the theoretical basis of the moderator effect of corporate characteristics on the causal link from corporate governance to the application of managerial accounting tools in business has not been argued or explored in the extant literature; therefore this study tries a tentative study on the moderator effect of corporate characteristics on that causal relationship. The interactive element is employed for the moderating analysis. The results indicate that the interactive element imposes a statistical impact on the application of managerial accounting tools with the influential coefficient of -0.335 at the $10 \%$ significance level (untabulated). That evidence implies that an increase in corporate characteristics by 1 unit will lessen the relationship between corporate governance and the application of managerial accounting tools within a firm by 0.335 units. As a result, corporate characteristics are statistically evidenced as a moderator in the causal linkage from corporate governance to the application of managerial accounting tools for a firm. Therefore, the causal association from corporate governance to the application of management accounting tools in business depends on corporate characteristics.

\section{Discussion}

Based on the corporate governance- management accounting- corporate characteristics triangular relationship, the current study makes some contributions to the management literature by investigating how corporate governance matters in transmitting corporate characteristics into the application of managerial accounting for a firm and also how corporate characteristics affect the corporate governance- management accounting causal link. The empirical results show that both corporate governance and corporate characteristics make contributions to the applying level of managerial accounting in business, consistent with the work of Erserim (2012; Htay and Salman, 2013), but corporate governance can be more important than corporate characteristics in boosting the application of managerial accounting systems in business, so firms should build a good corporate governance so as to enhance the application of managerial accounting in business, which will lead to more enhanced business performance. Additionally, the results also provide support that corporate governance structure is a consequence of corporate characteristics, in concurrence with the suggestion of Chadha (2015).

More importantly, this research finds out empirical support for the intervenient role of corporate governance on the application of managerial accounting and also the moderator effect of corporate characteristics in the research model. This finding is in accord with those of Mia (1988; Spencer, 2011; Baron and Kenny, 1986), which recommends that firms should decide on suitable managerial accounting tools to their corporate governance and corporate characteristics.

\section{Conclusion}

The causal linkages among the application of managerial accounting tools in business, corporate characteristics and corporate governance have been investigated in previous studies. Nonetheless, no research has examined the mediatory role of corporate governance on the causal relationship from corporate characteristics to the application of managerial accounting tools in business as well as the moderator impact of corporate characteristics on the association between corporate governance and the application of managerial accounting tools for a firm, although corporate governance is so much essential to the relationships among the application of managerial accounting tools, corporate characteristics and corporate governance. This research re-specifies the link between corporate governance and the application of managerial accounting tools. Then, it attempts to discuss 
and statistically examine the mediating influence of corporate governance on the causal link from corporate characteristics to the application of managerial accounting tools within an organization and also it explores the moderating effect of corporate characteristics on the causal association from corporate governance to the application of managerial accounting tools in business. The results point out that on the one hand, corporate characteristics and corporate governance both put statistical influences on the application of managerial accounting tools in business; on the other hand corporate governance statistically intervenes in the linkage between corporate characteristics and the application of managerial accounting tools in business, whereas corporate characteristics puts a moderating effect on the causal correlation from corporate governance to the application of managerial accounting tools in business. The current project offers contributions for the management knowledge with giving new empirical support on the mediatory role of corporate governance and the moderating role of corporate characteristics. When exploring the factors relevant to the application of managerial accounting tools in business, including corporate governance and corporate characteristics, scholars had better take the mediation of corporate governance as well as the moderation of corporate characteristics into account.

This research also provides executives with an insight into the complex relationships among the application of managerial accounting tools in business, corporate characteristics and corporate governance. Consequently, they are able to better decide on which managerial accounting tools in business are suitable to the corporate characteristics and corporate governance structure of the organization. This would help gain competitive advantages, which eventually lead to better corporate performance.

\section{Acknowledgment}

I am honestly thankful to Tra Vinh University for offering a research grant to carry out this project and especially I would like to express my thanks to the informants for their help in gathering the data.

\section{Ethics}

I have read and approved the manuscript and confirm that this work is original and unpublished elsewhere and no ethical issues involved.

\section{References}

Abdel-Kader, M.G. and R.G. Luther, 2008. The impact of firm characteristics on management accounting practices: A UK-based empirical analysis. Brit. Account. Rev., 40: 2-27.

DOI: $10.1016 / \mathrm{j}$. bar.2007.11.003
Agrawal, A. and S. Chadha, 2005. Corporate governance and accounting scandals. J. Law Econom., 48: 371-406. DOI: 10.1086/430808

Al-Mawali, H., 2015. Contingent factors of strategic management accounting. Res. J. Finance Account., 6: 130-137.

Al-Omiri, M. and C. Drury, 2007. A survey of factors influencing the choice of product costing systems in UK organizations. Manage. Account. Res., 18: 399-424. DOI: 10.1016/j.mar.2007.02.002

Altunoglu, A.E., 2012. Effects of environmental and organizational factors on corporate governance practices. Anadolu Univ. Soc. Sci. J., 12: 51-61.

Baron, R.M. and D.A. Kenny, 1986. The moderatormediator variable distinction in social psychological research: Conceptual, strategic and statistical considerations. J. Personality Soc. Psychol., 51: 1173-1182. DOI: 10.1037/0022-3514.51.6.1173

Bassiouny, S.W., M.M. Soliman and A. Ragab, 2016. The impact of firm characteristics on earnings management: an empirical study on the listed firms in Egypt. Bus. Manage. Rev., 7: 91-101.

Bhagat, S. and B. Bolton, 2008. Corporate governance and firm performance. J. Corporate Finance, 14: 257-273. DOI: 10.1016/j.jcorpfin.2008.03.006

Breen, J., N. Sciulli and C. Calvert, 2003. The use of computerized accounting systems in small business. Proceedings of the 16th Annual Conference of Small Enterprise Association of Australia and New Zealand, (ANZ' 03).

Brouthers, K.D., L.E. Brouthers and S. Werner, 2002. Industrial sector, perceived environmental uncertainty and entry mode strategy. J. Bus. Res., 55: 495-507. DOI: 10.1016/S0148-2963(00)00154-5

Brown, L.D. and M.L. Caylor, 2004. The correlation between corporate governance and company performances. Research study commissioned by Institutional Shareholder Services, USA

Cadbury, A., 1992. The Cadbury Committee Reports: Financial Aspects of Corporate Governance. 1st Edn., Burgess Science Press, London

Caldarola, R.A.L., 2016. Linking the balanced scorecard to organizational shareholders' expectations. Am. J. Econ. Bus. Admin., 8: 14-22. DOI: 10.3844 /ajebasp.2016.14.22

Chadha, P., 2015. Corporate governance and firm characteristics. Women's Institute for Studies in Development Oriented Management, Banasthali University, Rajasthan, India

Chen, X.D. and L.S. Fu, 2001. IT adoption in manufacturing industries: differences by company size and industrial sectors-the case of Chinese mechanical industries. Technovation, 21: 649-660. DOI: $10.1016 / \mathrm{S} 0166-4972(00) 00078-\mathrm{X}$ 
Chenhall, R.H. and D. Morris, 1986. The impact of structure, environment and interdependence on the perceived usefulness of management accounting systems. Account. Rev., 61: 16-35.

Christine, D., F.D. Birgit and M. Christine, 2011. Corporate governance and managerial accounting in family firms: Does generation matter. Int. J. Bus. Res.

Cinquini, L., P. Collini, A. Marelli and A. Tenucci, 2008. An exploration of the factors affecting the diffusion of Advanced Costing techniques: A comparative analysis of two surveys (1996-2005). Proceedings of the 31st Annual Congress of the European Accounting Association, (EAA' 08), Campus of Erasmus University, Rotterdam, Nederland.

Cromie, S., B. Stephenson and D. Monteith, 1995. The management of family firms: An empirical investigation. Int. Small Bus. J., 13: 11-34. DOI: $10.1177 / 0266242695134001$

Demsetz, H. and K. Lehn, 1985. The structure of corporate ownership: Causes and consequences. J. Polit. Econ., 93: 1155-1177. DOI: 10.1086/261354

Donna, F., H. Mahler and S. Cohen, 2011. How to conduct effective pretests. AIDSCAP's Behavior Change Communication (BCC) Unit, USA

Edwards, M. and R. Clough, 2005. Corporate governance and performance: An exploration of the connection in a public sector context. Corporate Governance ARC Project, University of Canberra, Australia.

Erserim, A., 2012. The impacts of organizational culture, firm's characteristics and external environment of firms on management accounting practices: An empirical research on industrial firms in Turkey. Proc. Soc. Behav. Sci., 62: 372-376. DOI: $10.1016 /$ j.sbspro.2012.09.059

Fisher, J., 1995. Contingency-based research on management control systems: categorization by level of complexity. J. Account. Literature, 14: 24-53.

Fullerton, R.R. and C.S. McWatters, 2001. The production performance benefits from JIT implementation. J. Operat. Manage., 19: 81-96. DOI: $10.1016 / \mathrm{S} 0272-6963(00) 00051-6$

Galbraith, J.R., 1973. Designing Complex Organizations. 1st Edn., Addison-Wesley Pub Co., MA, USA, pp: 150.

Hair, J.F., W.C. Black, B.J. Babin, R.E. Anderson and R.L. Tatham, 2010. Multivariate Data Analysis. 1st Edn., Pearson Prentice Hall, USA

Haldma, T. and K. Laats, 2002. Influencing contingencies on management accounting practices in Estonian manufacturing companies. Faculty of Economics and Business Administration, University of Tartu, Tartu.

Horngren, C.T., 1982. Cost Accounting: A Managerial Emphasis. 5th Edn., Prentice-Hall, New Jersey, USA, ISBN-10: 0131796712, pp: 997.
Hoque, Z., L. Mia and M. Alam, 2001. Market competition, computer-aided manufacturing and use of multiple performance measures: An empirical study. Brit. Account. Rev., 33: 23-45.

DOI: $10.1006 /$ bare. 2000.0149

Htay, S.N.N. and S.A. Salman, 2013. Balanced score card approach for better shari'ah corporate governance. Am. J. Applied Sci., 10: 1553-1557. DOI: 10.3844/ajassp.2013.1553.1557

Huynh, Q.L., 2015. The mutual relationship between corporate governance and management accounting: which occurs first? Am. J. Applied Sci., 12: 403-410. DOI: 10.3844/ajassp.2015.403.410

Hyvonen, J., 2005. Adoption and benefits of management accounting systems: Evidence from Finland and Australia. Adv. Int. Account., 18: 97-120. DOI: $10.1016 / \mathrm{S} 0897-3660(05) 18005-2$

Ibadin, P.O. and O. Imoisili, 2010. Organization contexts and management accounting system design: Empirical evidence from Nigeria. Int. J. Curr. Res., 10: 064-073.

Jensen, M. and W. Meckling, 1976. Theory of the firm: Managerial behavior, agency costs and ownership structure. J. Finan. Econ., 3: 305-360. DOI: 10.1016/0304-405X(76)90026-X

Johnson, H.T. and R.S. Kaplan, 1987. Relevance Lost: The Rise and fall of Management Accounting. 1st Edn., Harvard Business School Press, Boston, USA, ISBN-10: 0875842542, pp: 269.

Kaplan, R.S., 1983. Measuring manufacturing performance: A new challenge for managerial accounting research. Account. Rev., 58: 686-705.

Kaplan, R.S. and A.A. Atkinson, 1998. Advanced Management Accounting. 3rd Edn., Prentice Hall, New Jersey, USA.

Kyereboah-Coleman, A., 2007. Corporate Governance and Firm Performance in Africa: A Dynamic Panel Data Analysis. Proceedings of the International Conference on Corporate Governance in Emerging Markets, (GEM' 98), Sabanci University, Istanbul, Turkey.

Lucas, M., 1997. Standard costing and its role in today manufacturing environment. Manage. Account., 75: 32-35.

Mangantar, M. and M. Ali, 2015. An analysis of the influence of ownership structure, investment, liquidity and risk to firm value: Evidence from Indonesia. Am. J. Econom. Bus. Admin., 7: 166176. DOI: 10.3844/ajebasp.2015.166.176

Masrek, M.N., 2009. Determinants of strategic utilization of information systems: A conceptual framework, J. Software, 4: 591-598.

Mayer, F., 1997. Corporate Governance, Competition and Performance. In: Enterprise and Community: New Directions in Corporate Governance, Deakin, S. and A. Hughes (Eds.), Blackwell Publishers, Oxford, UK., 
Mellahi, K. and F. Eyuboglu, 2001. Critical factors for successful total quality management implementation in Turkey: Evidence from the banking sector. Total Q. Manage., 12: 745-756.

DOI: $10.1080 / 09544120120075352$

Mia, L., 1988. Managerial attitude, motivation and the effectiveness of budget participation. Account. Organiz. Society, 13: 46 5-475. DOI: $10.1016 / 0361-3682(88) 90017-7$

Miller, K.D., 1993. Industry and country effects on managers' perceptions of environmental uncertainties. J. Int. Bus. Stud., 24: 693-714. DOI: $10.1057 /$ palgrave.jibs.8490251

Nguyen, T.D., 2009. Decree No. 56/2009/ND-CP of 30 June 2009 on assistance to the development of small- and medium-sized enterprises. Vietnamese Government.

Nimtrakoon, S. and M. Tayles, 2010. Contingency factors of management accounting practices in Thailand: A selection approach. Asian J. Account. Governance, 1: 51-78. DOI: 10.17576/ajag-2010-1-6546

Nitaya, W., K. Isada, R. Sirirat and C. Worachatr, 2010. Factors affecting adoption of GL module of oracle and SAP accounting programs. Thammasat Bus. J., 31: 38-52.

Otley, D.T., 1999. Performance management: A framework for management control systems research. Manage. Account. Res., 10: 363-382. DOI: 10.1006/mare.1999.0115

Saad, S.M., S.N.S. Ahmad, K. Jusoff, M.M. Daud and M.A. Rahim, 2009. Income statements transparency and firms' characteristics of companies listed on the Bursa Malaysia. Am. J. Applied Sci., 6: 1718-1724. DOI: 10.3844/ajassp.2009.1718.1724

Salvato, C. and L. Melin, 2008. Creating value across generations in family-controlled businesses: The role of family social capital. Family Bus. Rev., 21: 259-275. DOI: $10.1177 / 08944865080210030107$

Sam, M.F.M., Y. Hoshino and M.N.H. Tahir, 2012. The adoption of computerized accounting system in small medium enterprises in Melaka, Malaysia. Int. J. Bus. Manage., 7: 12-25. 10.5539/ijbm.v7n18p12
Sankaran, S. and A. Kouzmin, 2005. Diffusion of Knowledge Management Systems: Mission Definitely Possible. 1st Edn., Emerald Group Publishing, UK, ISBN-10: 1845441214, pp: 106.

Sobel, M.E., 1982. Asymptotic confidence intervals for indirect effects in structural equation models. Sociol. Methodol., 13: 290-312. DOI: 10.2307/270723

Soltani, B., 2005. Factors Affecting Corporate Governance and Audit Committee in Selected Countries. 1st Edn., The Institute of Internal Auditors, Research Foundation, USA, ISBN-10: 0894135562, pp: 190.

Spencer, D.L., 2011. Testing mediation using multiple regression and structural equation modeling analyses in secondary data. Evaluat. Rev., 35: 240-268. DOI: 10.1177/0193841X11412069

Taha, A., H. Etemadi and A. Pifeh, 2011. Exploration of factors influencing on choice the activity-based costing system in Iranian organizations. Int. J. Bus. Admin., 2: 61-70. DOI: 10.5430/ijba.v2n1p61

Wang, D.H.M. and Q.L. Huynh, 2014. Linkages among corporate governance, management accounting practice and organizational performance: Evidence from a southeast Asian country. Romanian Econ. Bus. Rev., 9: 63-81.

Warwood, S. and P. Roberts, 2004. A survey of TQM success factors in the UK. Total Quality Manage. Bus. Excellence, 15: 1109-1117. DOI: $10.1080 / 1478336042000255460$

Waterhouse, J. and P. Tiessen, 1978. A contingency framework for management accounting systems research. Account. Organiz. a Society, 3: 65-76. DOI: 10.1016/0361-3682(78)90007-7

Waweru, N.M. and G.K. Riro, 2013. Corporate governance, firm characteristics and earnings management in an emerging economy. J. Applied Manage. Account. Res., 11: 43-64.

Wierenga, B. and P.A.M.O. Ophuis, 1997. Marketing decision support systems: Adoption, use and satisfaction. Int. J. Res. Market., 14: 275-290. DOI: 10.1016/S0167-8116(97)00009-8 